\title{
LEGAL AND INSTITUTIONAL FRAMEWORKS AND PARTICIPATION OF POLITICAL PARTIES IN THE ELECTIONS TO LEGISLATIVE SEJM IN 1919 IN THE PODKARPACIE REGION
}

\begin{abstract}
The article presents preparation and the conduct of parliamentary elections in the Podkarpacie Region to the first parliament in the history of the reborn Second Republic, namely the Legislative Sejm, that was to adopt a new constitution. The notions of a political party during the creation of an independent Polish state were defined and the formation of institutions and law, which were responsible for the conduct of elections, were presented. The Podkarpacie Region in the period of the Second Republic was not separated administratively as today, but it was known geographically and historically. Geographically it coincided with the so-called Central Malopolska areas, which was a part of a larger whole that was Galicia, associated mainly with the western and eastern part. In the article the first normative acts on the first elections in independent Polish state after 1918 were discussed. The author paid attention to the electoral law and several other smaller acts. There are also presented the number of the authorized to vote and voters, valid and invalid votes, and a voter turnout in constituencies in the Podkarpacie Region in the elections of 26 January 1919 to the Legislative Sejm, and the distribution of political support in individual constituencies of the Podkarpacie Region. The area of the Podkarpackie Region included the following electoral districts: Nowy Sacz No. 40, Jasło No. 41, No. 42 Tarnów, Rzeszów 43, Tarnobrzeg No. 44, No. 45 Jarosław, Przemysl 46. These districts were determined politically in the context of the ongoing struggle for the borders, they did not overlap with some of the districts, but from the geographical point of view they fitted in with the area of Podkarpacie.
\end{abstract}

Keywords: The Podkarpacie Region, elections of 1919, Legislative Sejm, political parties, the Second Republic.

\section{INTRODUCTION}

Over the years the concept of the Podkarpacie Region, whose area was understood differently depending on ages, arose. The Podkarpacie Region territory in administrative terms was not separated in the Second Republic, although this concept was geographically known. It was introduced to the administrative language for good together win the administrative reform of provinces in 1998 and since then the concept of the Podkarpacie Region has been fully shaped ${ }^{2}$. Previously, the region oscillated between two metropolitan

${ }^{1}$ Krzysztof Surowiec, M.A., assistant in Department of Humanities, Faculty of Management, Rzeszow University of Technology, e-maila: ks@prz.edu.pl

${ }^{2}$ The Act of 24 July 1998 on the introduction of the three-tier division of the state (JOL of 1998, no. 96 item 603). 
centers, it is Cracow and Lviv. Hence the political geography had to be diverse as varied were the economic, social and ethnic conditions in the area. Another functioning concept to define Podkarpacie that occurs and has been adopted by researchers of the peasant movement in the region is the name of the Central Lesser Poland and Central Galicia. This last name is rather a symbolic term and it does not exist either in contemporary official sources or private ones. Podkarpacie was divided between two provinces: Lviv and Cracow. It consisted of the following counties: Tarnobrzeg, Nisko, Kolbuszowa, Łańcut, Rzeszów, Przeworsk, Jarosław, Lubaczów, Przemyśl, Strzyżów, Brzozów, Krosno, Sanok, Lesko, Rawa, Dobromil and Sokal, Mielec, Dębica, Jasło, Dąbrowa, Tarnow, and Gorlice. Also, after World War II, these sites were included in the administration of the two provinces Rzeszow and Cracow. Administrative reform in force since 1 June 1975 divided the Podkarpacie Region between the newly separated provinces: Rzeszow, Przemyśl, Krosno, Nowy Sacz, Tarnów and Tarnobrzeg ${ }^{3}$. Finally, the recent local government reform, in force since 1 January 1999, divided the Podkarpacie between the following provinces: Podkarpackie and Lesser Poland ${ }^{4}$. In this article the term Podkarpacie will be covered in general by the western counties of the historic province of Lviv and eastern counties of the historic province of $\mathrm{Cracow}^{5}$. When it comes to the contemporary Polish administrative map, the examined area of the Podkarpacie Region includes the entire Podkarpackie Province and eastern districts of the Małopolska Province. The data on the elections and their results to the Sejm of the Second Republic will be based on the borders of individual constituencies, which sometimes exceeded its reach beyond the boundaries of administrative divisions (mainly in terms of counties).

In the Polish legislation during the Second Republic it was not possible to find a definition of a party or a political party. However, the doctrine of law has developed such a concept. Professor Zygmunt Cybichowski determined by a political party, "a cluster of people that has a common political program, concerning the tasks of the state. ${ }^{6 "}$ The author in its definition did not add the word "organized", explaining that the party cannot exist without an organization. It also implied that the anarchists and nihilists can never be a party, because they do not recognize the state ${ }^{7}$. Another definition of a party was quoted by Ludwik Kulczycki. According to him, a political party is "a union of people, united on the basis of a specific political, social or economic program. ${ }^{8 "}$

Today, the party is referred to "a voluntary political organization whose aim is to gain and maintain power on the basis of the presented program, in the way of free elections,

3 JOL, no. 16 item.91 of 1 June 1975.

4 JOL, no. 96 item 603 of 28 July 1998.

${ }^{5}$ Compare:. Ruch ludowy na Rzeszowszczyźnie. Materiaty z sesji naukowej zorganizowanej przez WK ZSL w Rzeszowie z okazji 70-lecia ruchu ludowego, ed. S. Jarecka-Kimlowska, Lublin 1967, pp. 5-11.

6 Z. Cybichowski, Polskie prawo państwowe, Warszawa 1925, p. 57.

${ }^{7}$ Anarchism - characterized by aversion to centralized power and institutions. Nihilism (from the Latin. Nihil - nothing) - philosophical view completely or partially negating the existence of certain

entities.

${ }^{8}$ Ibidem. 
which holds already gained authority on the basis of the methods of democracy and the rule of law." 9

At some glances at parties its role as a link between citizens and the government emphasizes. In such a way a party was defined by i.a. Sigmund Neumann and Kay Lawson. Neumann defined the party as follows: "a separate organization of politically active social actors, who are interested in controlling the executive power and who compete for public support of another group or groups with different views" ${ }^{10}$. Kay Lawson defined the party as "an organization uniting individuals who seek electoral and non- electoral support from the public or its part for its representatives, in order to be able to exercise political power associated with specific positions of government, claiming that power is exercised for the social good" ${ }^{11}$.

The research problem of this article is the following: how the results of the first elections to the Legislative Sejm in 1919 looked like in the Podkarpacie Region? The aim is to present the importance of the first few months of independence of the Second Republic and its normative achievements in the organization of elections and their conduct. The research covered the period from November 1918 to February 1919 in the Podkarpacie Region. The main hypothesis of the research is summed up in the statement that the results of the elections of 1919 to the Legislative Sejm and high win of the party derived from the popular movement for a long period cemented their influence in Podkarpacie during the Second Republic period.

\section{LEGAL AND INSTITUTIONAL FRAMEWORK FOR ELECTIONTO LEGISLATIVE SEJM IN JANUARY 1919}

On November 18, 1918 Ignacy Daszyński was replaced as prime minister by Jędrzej Moraczewski, a politician who derived from the Polish Social Democratic Party of Galicia and Cieszyn Silesia. On November 20, 1918 he announced the government of Moraczewski announced the program, which emphasized its temporary nature and the desire to fulfill the obligations of state only until the election and constitution of the Legislative Sejm. It also referred to the future ordination. "Preparations for this act start immediately, and the electoral law will be announced by us in the coming days" ${ }^{12}$. With these words, the government of Moraczewski assured all political groups that the elections to the Constituent Assembly was the most important objective for it. According to Piłsudski: "True representation will give general elections to the parliament, which must

\footnotetext{
${ }^{9}$ Parties as key institutions of a democratic state are being explicitly guaranteed in the Constitution or laws that ensure political pluralism, freedom of creation, freedom of action and the equality of all parties. In Poland, such provisions are contained in the Basic Law of 1997 which in the Article 11 resolves that: "The Republic of Poland shall ensure freedom for the creation and functioning of

political parties. Political parties associate on a voluntary basis and equality of Polish citizens to influence by democratic means to shape state policy. " JOL 1997, no. 78, item. 483. A similar regulation exists in the Law on Political Parties of 27 June 1997. JOL 1997, no. 98, item 604.

${ }^{10}$ S. Naumann, Modern Political Parties, Chicago 1958, p. 396.

${ }_{11}$ K. Lawson, The Comparative Study of Political Parties, New York 1976, pp. 3-4.

${ }^{12}$ Polish Monitor no. 208 of 20 November 1918.
} 
obey all the groups and parties. [...] The way by elections will lead to the will of the people"13.

These assumptions of Józef Piłsudski were being passed in the decree issued by the supreme authority of the representative of the Polish Republic of 22 November 1918. This was an important act of state, and on its basis the state authorities were supposed to function until the convening of the Legislative Sejm. Józef Piłsudski took the position of the Provisional Head of State. Legislative power was exercised by the Council of Ministers and the Head of State who approve it. Electoral law to the Legislative Sejm was adopted on 28 November $1918^{14}$, it was also introduced a decree managing elections to the Legislative Sejm on the same day ${ }^{15}$.

Electoral law to the Legislative Sejm consisted of 101 articles and 5 appendices. to the The first two chapters were devoted to the right to stand in elections and for elections; others concerned the rights of citizens regarding the reporting of candidates for deputies, the formation of election commissions, the right to check the lists of electors, the act of voting and the right to complaint ${ }^{16}$. In the first chapter, which concerned the right to vote, the Article 1 conceded the right to vote to persons who were 21 years of age at the date when the elections were announced. At that time this was the limit widely believed as the best possible to accept ${ }^{17}$. It did not predict any discrimination based on sex. One can see in this record that the low age census was imposed, which sparked controversy. In the case of the right to stand in elections a citizen had to meet the domicile census, that is, to live in his polling area at least the day before the election decree (art. 2); this condition did not concern the right to stand for elections (art. 7). The domicile census was formed quite liberally - it was enough to have a residence at least the day before the announcement of elections. Such a solution was opposed as it was virtually impossible for job seekers who moved around the country to vote. It was postulated that a voter should be entitled to vote where they could identify at least three-month residence.

On the basis of the electoral law (art. 3), a voter could only vote in one district. With regard to the limitations of voting rights the decree deprived the right to vote of all active soldiers on active duty (art. 4), and criminals without judgment of the court of civil rights (art. 5). In the last article (art.6) of the first chapter, it was stated that a vote should be made in person.

The right to stand for election (art. 7) had all citizens (including the servicemen) who had the right to vote without any restrictions because of the place of residence. Also this article as art. 1 and 2 was not precise, because to have the right to vote, one had to have a right to stand in elections, and this in turn was dependent on the residence. However, the deprivation of active military men from voting was welcome, which protected the servicemen from political wrangling, but let them to apply. Such a regulation was in line with the contemporary principle of political neutrality of the army - "the army is a big

${ }^{13}$ Polish Monitor no. 229 of 14 December 1918.

14 Journal. Pr. P. P., no. 18 item 46 of 6 December 1918.

15 Journal Pr. P. P., no. 18 item. 47 of 6 December 1918.

${ }^{16}$ Journal Pr. P. P., no. 18 item 46 of 6 December 1918.

${ }^{17}$ K. Skotnicki, Zasada powszechności w prawie wyborczym - zagadnienia teorii i praktyki, Łódź 2000, p. 105 
dumb." ${ }^{18}$ Thanks to it future parliaments, not just Legislative ones gained in their benches eminent specialists in the field of defense.

Further articles of the ordination (8-10) contained the following restriction in selecting members. It was forbidden to select public servants administrative, fiscal and judicial districts authorities where their power extended. However, this provision did not apply, military officials and the central government. All officials and the military, who were elected to parliament, had to release themselves from their official duties, for the time of carrying out the mandate ${ }^{19}$. During the service as MPs they did not receive remuneration from their previous office. Regulations did not contain provisions relating to diet, what could stop, according to Wacław Komornicki, the adoption of parliamentary mandates by less prosperous candidates ${ }^{20}$. The third chapter dealt with the ordination of electoral districts and voting circuits. Poland was divided into constituencies, whose list and the main hubs of the electoral commissions were set out in Appendix 1 to the electoral law (art. 11). Ordinance divided an area where the elections were to be held into 71 districts (later 70 as a result of the merger of 35 (Cieszyn) and 35 A (Frydek) districts.

As a result of the Moraczewski government it was assumed that the new parliament would have 524 seats, which was most fully reproduce the will of the voters, but it never happened. It ruled out the idea of forming small constituencies ${ }^{21}$. Nationally, medium and large constituencies dominated. The whole area of Galicia was divided into 24 constituencies, and together with Silesia Cieszyn it had 26 districts. Finally, it was possible to get 171 seats.

Chapter Four art. 14-87 dealt with the election of deputies. They were to be managed by the Head of State. They should fall on a Sunday or holiday, one day throughout the country. The order of elections was to be published in the Official Rights Register of the Polish State and in the official political, capital and provincial registers. Voting should be established no later than 60 days after the election of management, and the date of announcement of elections in the Official Rights Register was considered automatically for the day of ordering the election. Chapter five of the ordination concerned the validity of credentials. Every citizen could lodge a protest against the election within 14 days after the announcement of voting results by the Central Electoral Commission. It was the most important provisions of the first electoral law after Poland regained its independence in 1918.

\section{ELECTONS FOR LEGISLATIVE SEJM IN THE PODKARPACIE}

\section{REGION}

Elections for the new Legislative Sejm took place on 26 January 1919, a week after the first parliamentary elections in the newly created Republic of German (Weimar) were held and well ahead of the parliamentary elections in other newly established countries of Central and South America. They are characterized by a very high voter turnout of up to $90 \%$ and even $95 \%$ of those eligible. The first meeting of the Legislative Sejm, acting as a

\footnotetext{
18 A. Ajnenkiel, Parlamentaryzm II Rzeczypospolitej, Warszawa 1975, p. 107.

${ }^{19}$ Understood as a leave.

${ }^{20}$ W. Komarnicki, Polskie prawo polityczne, Warszawa 2008, p. 58.

${ }^{21}$ This concept found its support, e.g. by W. Jodko-Narkiewicz, but Komarnicki spoke about it in quite a different tone.
} 
Constituent Assembly, was held on 10 February 1919. The speaker of the Legislative Sejm was Wojciech Trąmpczyński.

Legislative Sejm sitting in the years 1919-1922, the first parliament in the independent Republic played an important role in building the foundations of a new political system of the Republic. It was selected partly through democratic five-adjective elections (direct, universal, equal, secret and proportional) and on 26 January 1919 it was supplemented by the Polish parliament deputies. It was gradually supplemented during elections in individual districts until 1922. In the course of work on the ordination of the future Constituent Assembly it decided that it would be a unicameral body ${ }^{22}$. It had great symbolic significance, was a clear sign of revived Polish state after a period of captivity, it was also an expression of national sovereignty. It was also a body of "sovereign and the legislature power," the task of going beyond the obligation to develop a proper constitution.

The conducted election campaign to the Legislative Sejm took place in a complex external situation of the state and even more tense internal situation ${ }^{23}$. The Moraczewski government, increasingly under attack of political opponents, prepared (signed by the Head of State on January 2, 1919.) decree on the state of emergency, allowing the Council of Ministers its introduction as needed throughout the country or its part ${ }^{24}$. After the failed coup attempt organized by the right wing, connected with deprivation of liberty of government on the night of 3 to 4 January, the government took advantage of their authority and on January 5, 1919 announced a period of three months of the state of emergency in Warsaw and the Warsaw district, and in the counties of Dąbrowa and Będzin.

At the commencement of the deliberation Legislative Sejm counted 335 members ${ }^{25}$, but in the following months the number of members grew steadily until March 1922, when the Sejm counted (already permanently until the end of term) 432 members.

In the elections to the Legislative Sejm of 26 January 1919 the Podkarpacie area was included in the following electoral districts: Nowy Sącz No. 40, Jasło No. 41, Tarnów No. 42, Rzeszów No. 43, Tarnobrzeg No. 44, Jarosław No. 45, Przemyśl No. 46. These counties were designated ad hoc as a part of the ongoing struggle for the borders, they did not coincide with counties, but from the point of view of geographical overlap with the area of Podkarpacie. Only weakly populated areas in the southeast of Sanok and Przemyśl were not included in the mentioned districts in these elections. This was also connected with the ongoing struggles in these areas border with Ukrainians and poorly organized Polish administration, especially this elective one. These areas were not incorporated into the new constituencies until future elections in November 1922.

\footnotetext{
${ }^{22}$ A. Ajnenkiel, Spór o model parlamentaryzmu polskiego do 1926 r., Warszawa 1972, pp. 160162 ;

M. Pietrzak, Parlament Drugiej Rzeczypospolitej, [in:] Spoleczeństwo obywatelskie i jego reprezentacja (1493-1993), red. J. Bardach, W. Sudnik, Warszawa 1995, p. 141.

${ }^{23}$ A. Ajnenkiel, Narodziny parlamentaryzmu II Rzeczypospolitej, [in:] Konstytucja 3 Maja i jej tradycje, Wrocław 1992, pp. 67.

${ }^{24}$ Decree on 2 January 1919 about the martial law, JOL Pr. P. P. 1919, no. 1 item 79.

25 According to data from April 1919 there were 348; the Sejm note „The list of MPS to Executive Sejm of the Polish Republic on z dnia 12 April 1919", followed: S. Krukowski, Sejm Ustawodawczy 1919-1922, „Czasopismo Prawno-Historyczne” 1986, z. 1, p. 97.
} 
Westernmost situated electoral districts of Tarnów and Nowy Sącz did not belong to Podkarpacie, but due to the fact that the MPs were elected from the whole constituency, they had been included in the western borders of Podkarpacie. In other border points of Podkarpacie it was not the problem, because they were designated by such big centers like Tarnobrzeg, Przemyśl and Sanok. In 11 constituencies Galicia where 979099 people voted, 71 deputies were elected ${ }^{26}$. The boycott by the communists and Jewish party "Bund" was not successful.

The detailed information related to the elections to the Legislative Sejm constituencies in Podkarpacie is presented in Table 1, in particular as regards the number of voters and those who gave their vote.

Table 1. The number of authorized to vote and voters, valid votes and invalid, and turnout in constituencies of Podkarpacie in the elections of 26 January 1919 to the Legislative Sejm

\begin{tabular}{|c|c|c|c|c|c|}
\hline $\begin{array}{c}\text { Electoral } \\
\text { constituencies, } \\
\text { districts and towns }\end{array}$ & $\begin{array}{l}\text { No. of eligible } \\
\text { to vote }\end{array}$ & No. of voters & $\begin{array}{c}\text { No.of valid } \\
\text { votes }\end{array}$ & $\begin{array}{c}\text { No. of invalid } \\
\text { votes }\end{array}$ & $\begin{array}{c}\text { Election } \\
\text { turnout }\end{array}$ \\
\hline District 40 & 95941 & 78041 & 77733 & 308 & $81,34 \%$ \\
\hline Gorlice & 25350 & 19407 & 19281 & 126 & $76,56 \%$ \\
\hline Grybów & 19339 & 16384 & 16329 & 55 & $84,72 \%$ \\
\hline Nowy Sącz & 51252 & 40836 & 40709 & 127 & $79,68 \%$ \\
\hline District 41 & No data & 71238 & 71073 & 165 & No data \\
\hline Jasło & & 27957 & 27880 & 77 & \\
\hline Krosno & & 27107 & 27060 & 47 & \\
\hline Sanok & & 16174 & 16133 & 41 & \\
\hline District 42 & 185473 & 156727 & 156727 & (b.d.) & $84,50 \%$ \\
\hline Brzesko & 44036 & (b.d.) & 37480 & (b.d.) & $85,11 \%$ \\
\hline Bochnia & 48128 & (b.d.) & 40537 & (b.d.) & $85,23 \%$ \\
\hline Dąbrowa & 28375 & (b.d.) & 24150 & (b.d.) & $85,11 \%$ \\
\hline Pilzno & 19645 & (b.d.) & 16337 & (b.d.) & $83,16 \%$ \\
\hline Tarnów & 45289 & (b.d.) & 38223 & (b.d.) & $84,40 \%$ \\
\hline District 43 & $92202 *$ & 95341 & 94715 & 626 & (b.d.) \\
\hline Ropczyce & 32221 & 28154 & 28038 & 116 & $87,38 \%$ \\
\hline Rzeszów & 59981 & 48293 & 48084 & 209 & $80,51 \%$ \\
\hline Strzyżów & (b.d.) & 18894 & 18593 & 301 & (b.d.) \\
\hline District 44 & 119381 & 97098 & 96420 & 678 & $81,33 \%$ \\
\hline Kolbuszowa & 28494 & 22797 & 22480 & 317 & $80,01 \%$ \\
\hline Mielec & 30583 & 26226 & 26162 & 64 & $85,73 \%$ \\
\hline Nisko & 25553 & 18125 & 17869 & 256 & $70,93 \%$ \\
\hline Tarnobrzeg & 34751 & 29950 & 29909 & 41 & $86,18 \%$ \\
\hline District 45 & 109078 & 74334 & 74122 & 212 & $68,15 \%$ \\
\hline Jarosław & 48241 & 27356 & 27267 & 89 & $56,71 \%$ \\
\hline Łańcut & 37468 & 27830 & 27743 & 87 & $74,28 \%$ \\
\hline Przeworsk & 23469 & 19148 & 19112 & 36 & $81,59 \%$ \\
\hline District 46 & 83858 & 49966 & 49792 & 174 & $59,58 \%$ \\
\hline Brzozów & 31327 & 22372 & 22245 & 127 & $71,41 \%$ \\
\hline Przemyśl & 45264 & 23946 & 23917 & 29 & $52,90 \%$ \\
\hline Bircza & 7267 & 3648 & 3630 & 18 & $50,20 \%$ \\
\hline
\end{tabular}

${ }^{26}$ A. Ajnenkiel, Historia sejmu Polskiego, vol. II, part 2, II Rzeczpospolita, Warszawa 1989, p. 16-17. 


\begin{tabular}{|l|l|c|c|c|c|}
\hline Overall & $\mathbf{6 8 5 9 3 3} * *$ & 622745 & $\mathbf{6 2 0 5 8 2}$ & $\mathbf{2 1 6 3} * * *$ & $\mathbf{x}$ \\
\hline $\begin{array}{l}\text { Turnout average } \\
\text { from five electoral } \\
\text { districts }\end{array}$ & $\mathrm{x}$ & $\mathrm{x}$ & $\mathrm{x}$ & $\mathrm{x}$ & $\mathbf{7 4 , 9 8 \%}$ \\
\hline
\end{tabular}

* Without data from Strzyżów district

** Without ineligible to vote in district no. 41

*** Without the numer of invalid votes in the district no. 42

Source: Own studies based on: L. Krzywicki, Statystyka wyborów do Sejmu Ustawodawczego, Warszawa 1921, s. 1-100.

Table 1 shows that, compared with the election results from individual districts the most people eligible to vote was on the Podkarpacie in district No. 42 (Tarnów), the second place was District No. 44 (Tarnobrzeg) and the third in district No. 45 (Jarosław ). The most eligible voters in smaller electoral districts included in the electoral constituencies in the county was in a political district of Rzeszów - 59981 people. All voters in the seven surveyed districts of the Podkarpacie region were eligible to vote, on the basis of certain data was approx. 685933 persons, including to the approximate number of voters of District 41 (Jasło), on the basis of votes the figure rises to approx. 760 000 of eligible votes. According to the calculations of Ludwik Krzywicki, in Galicia there were 169668 eligible voters. It means that the Podkarpacie districts accounted for the vast majority when it comes to the number of people eligible to vote.

In all seven districts the number of voters who voted were known. Most of them were from the district No. 42 (Tarnów), the second place was district No. 44 (Tarnobrzeg), where voted more than 50 thousand voters less. When it comes to smaller political districts the available data show that in Podkarpacie the most votes were in the political district of Rzeszów - 48 293. However, we do not have partial data from the districtNo. 42 , where there was absolutely the most votes in all constituencies. On the whole in Podkarpacie voted 622745 voters, which accounted for almost half of the holders of Galicia, where it was possible to hold the elections. In seven districtsof Podkarpacie only two thousand votes were invalid (without voting rights revoked in district No. 42, the lack of data) out of 622 thousand votes, which constituted a very small percentage. Most of invalid votes were in the district No. 44 (Tarnobrzeg) - 678, while most unimportant in units of lower level - in the political district in Kolbuszowa - 317, which also belonged to the district no. 44. The least of invalid votes were in Bircza - only 18, which was part of district No. 46 (Przemyśl), but this district had very few voters, only 7267 people. The second place, more statistically representative, had the political district of Przemyśl, which was a part of the district No. 46, and where there were only 29 invalid votes.

The biggest turnout was recorded in Podkarpacie in district No. 42 (Tarnów) $84.50 \%$, and the smallest in the district No. 46 (Przemyśl) - 59.58\%. The average attendance in seven constituencies of Podkarpacie amounted to $74.98 \%$. The highest voter turnout was recorded in Podkarpacie political district Ropczyce, which was up $87.38 \%$.

The data by Ludwik Krzywicki concern 7 constituencies in the area of Podkarpacie where voters voted in 23 political districts and one judicial district (Bircza - located on the south-eastern edge of Podkarpacie between Przemyśl and Sanok). Voting took place in 1974 districts, an average of 282 districts in a single constituency. The most voting districts to vote was in district 42 (Tarnów), as many as 524, while the least in the district 
46 (Przemyśl), because only 160. In the judicial district of Bircza, there were only 26, due to the small population and an irregular situation to the east and south of Bircza in connection with the ongoing fighting with the Ukrainians. The most voting districts was in the political district of Rzeszów (159) and Nowy Sącz (151).

\section{CONCLUSION}

The highest number of votes at 622745 during the elections received PSL "Piast", as many as 263000 , which accounted for $42 \%$ of all votes. "Piastowcy" achieved a great victory but also other people's parties achieved good results depending on the party and the district, which was linked to a party starting in the election. The most votes PSL "Piast" won in the district no. 42 - 96 030. The district was composed of five political districts: Bochnia, Brzesko, Dabrowa, Pilzno and Tarnów. The second district where "Piast" achieved excellent result was district no. 43 (Rzeszów), where they won 51204 votes. The party won the least votes in the district No. 44 (Tarnobrzeg) - because only 8 358. This was due to the fact that in the district "Piast" had a strong competitor in the person of the priest Okon and his radical supporters gathered around the PSL-Left PSL "Liberation" and the Radical Peasant Party. The Radicals won in this district as many as 75673 votes, the most in Tarnobrzeg, it was still the aftermath of the existence of the Republic of Tarnobrzeg and support of the revolutionary slogans by impoverished peasants who expected that their financial situation would improve due to breaking up large estates and funds drawn from Soviet Russia. On the whole Podkarpacie radical peasant parties (PSL-Left, supporters of the priest Okoń, PSL "Liberation") received 142 974 votes, which accounted for almost $23 \%$ of the votes. Overall, the people's parties in Podkarpacie received support in the elections to Legislative Sejm in the amount of approx. $65 \%$.

Polish Social-Democratic Party, or the socialists won the support of 62486 voters, which accounted for $10 \%$. Most support the party received in the western and central districts of Podkarpackie, the farther east of Rzeszów support for PPSD decreased. Socialists in the whole country, including the main leftist party, or Polish Socialist Party, who did not compete in Galicia, recognized the elections to the Legislative Sejm as their defeat. According to the same socialist it was primarily due to the collapse of the government of Jędrzej Moraczewski. They said nothing about allegations of election fraud and the slow fall in revolutionary sentiment associated with the completion of the military operations (not counting the battle about the borders) and increased economic security among the population. From the areas of Podkarpacie they managed to get seats in the Sejm, which was only thanks to the activities of PSDP Galicia and Cieszyn Silesia. The greatest support PSDP received P in district No. 40 (Nowy Sącz) and 42 (Tarnów), which won respectively 12020 and 10987 votes.

Parties of the right wing centered in the national movement (the National Electoral Committee Democratic Parties) also failed to achieve electoral success in Podkarpacie as it was in the former Congress constituencies, or later in the elections in Poland and Pomerania. National Democrats with the Christian Democrats treated as a right party won in Podkarpacie 91396 votes, which represented 14.5\% of the votes, this enabled the introduction to the parliament a number of members from the right wing. National Democrats managed to win a number of voices in the district No. 40, where the Municipal National Organization received 5148 and the Union of Catholic 13019 votes. In the 
Nowy Sacz district both parties together received 10329 votes out of 40836 voters. In the district no.42 right-wing forces celebrated the greatest victory, the National Democracy did not receive too many votes, but the Polish Association of Catholic People won as many

26937 votes, including Tarnów 10096 votes. The biggest defeat for the National Democratic Party was in the district o. 43 (Tarnobrzeg), where they enjoyed the support of the only 2574 voters, while in the district 97098 people. In the district of Przemyśl (46) the right-wing ideology was popular in connection with ethnic problems in these areas and as a result of proximity of passing fronts during the Polish-Ukrainian war. As a result, National Democracy won the general 10591 votes out of 49966 voters. It means that National Democracy got the support of $76 \%$.

National minority parties won 35,440 votes, which constituted $5.7 \%$ of public support. The Jewish lists were supported in district 42 (Tarnów), with 10,128 votes, followed by districts 40, 41, 43 and 44. In each of them, the Jewish lists won over five thousand votes. Major successes the minorities reached in the districts of Tarnów, Bochnia and Rzeszów.

Elections to the Legislative Sejm showed that a very significant part of the Jewish community in Poland, and especially in Galicia (Podkarpacie), was based on Jewish nationality, and was not limited to the role of the religious community. Even the differences of views between the Jewish parties and the Zionists to the workers' parties did not undermine unanimity in recognizing Jews as nationality. In order to weaken their representation in the next parliament elected in 1919, the electoral law included the larger urban districts, particularly in Galicia (Podkarpacie, in Eastern Galicia, where the Jewish population could count on many votes), those of predominantly Jewish population to large districts rural areas where the Jewish population was small. Polish deputy had to get on average between 12000 and 20000 votes, and the elected Jewish deputies had 45,000 votes. In this way the Jewish population in Poland at that time was represented by about $11 \%$ of the entire population and was represented in the new parliament by about $3 \%$ of the parliamentary representation.

The rest of the support was shared between local parties and unions that did not play any part in the electoral process in Poland, Galicia and even Podkarpacie. They fought for support of their programs in the planned municipal and local elections, where they were supposed to play a much bigger role than in the parliamentary elections.

\section{REFERENCES}

[1] Ajnenkiel A., Historia sejmu Polskiego, vol. II, part 2, II Rzeczpospolita, Warszawa 1989.

[2] Beck P.A., Party Politics in America, New York 1979.

[3] Biliński L., Wspomnienia i dokumenty 1846-1922, vol. 2, Warszawa 1935.

[4] Cybichowski Z., Polskie prawo państwowe, Warszawa 1925.

[5] Dekret Naczelnika Państwa z dnia 22 listopada 1918 r. o najwyższej władzy reprezentacyjnej Republiki Polskiej, Dz. Pr. P. P., Nr 17 poz. 41 z dn. 29 listopada $1918 \mathrm{r}$.

[6] Dekret z dnia 2 stycznia 1919 r. o stanie wojennym, Dz. Pr. P. P. 1919, Nr 1 poz. 79. 
[7] Dekret zarządzający wybory do Sejmu Ustawodawczego, Dz. Pr. P. P., Nr 18 poz. 47 $\mathrm{z}$ dn. 6 grudnia $1918 \mathrm{r}$.

[8] Halpern L., Polityka żydowska w Sejmie i Senacie Rzeczypospolitej Polskiej 1919-1933, Warszawa 1933.

[9] Hupka J., Z czasów wielkiej wojny, Lwów 1937.

[10] Komarnicki W., Polskie prawo polityczne, Warszawa 2008.

[11] Konstytucja Rzeczypospolitej Polskiej z dnia 2 kwietnia 1997 r. uchwalona przez Zgromadzenie Narodowe w dniu 2 kwietnia 1997 r., przyjęta przez Naród w referendum konstytucyjnym w dniu 25 maja 1997 r., podpisana przez Prezydenta Rzeczypospolitej Polskiej w dniu 16 lipca 1997 r. (Dz. U. 1997, nr 78, poz. 483).

[12] Krukowski S., Sejm Ustawodawczy 1919-1922, „Czasopismo Prawno-Historyczne” 1986, z. 1.

[13] Krzywicki L., Statystyka wyborów do Sejmu Ustawodawczego, Warszawa 1921.

[14] Kulczycki L., Nauka o państwie, Warszawa 1929.

[15] Lawson K., The Comparative Study of Political Parties, New York 1976.

[16] Monitor Polski nr 208 z 20 listopada 1918 r.

[17] Monitor Polski nr 219 z 3 grudnia 1918 r.

[18] Monitor Polski nr 229 z 14 grudnia 1918 r.

[19] Naumann S., Modern Political Parties, Chicago 1958.

[20] Niepodległość, 1937, v. XV.

[21] Ordynacja wyborcza do Sejmu Ustawodawczego z dnia 28 listopada 1918 r., Dz. Pr. P. P., nr 18 poz. 46 z dn. 6 grudnia 1918 r.

[22] Pietrzak M., Parlament Drugiej Rzeczypospolitej, [in:] Społeczeństwo obywatelskie i jego reprezentacja (1493-1993), ed. J. Bardach, W. Sudnik, Warszawa 1995.

[23] Przegląd Gospodarczy 1921, no. 12.

[24] Rozporządzenie Rady Ministrów z dnia 5 stycznia 1919 r. o wprowadzeniu stanu wyjątkowego w st. m. Warszawie i w pow. Warszawskim, Dz. Pr. P. P. 1919, nr 2, poz. 82.

[25] Ruch ludowy na Rzeszowszczyźnie. Materiały z sesji naukowej zorganizowanej przez WK ZSL w Rzeszowie z okazji 70-lecia ruchu ludowego, ed. S. Jarecka-Kimlowska, Lublin 1967.

[26] Skotnicki K., Zasada powszechności w prawie wyborczym - zagadnienia teorii i praktyki, Łódź 2000.

[27] Ustawa z dnia 24 lipca 1998 r. o wprowadzeniu zasadniczego trójstopniowego podziału terytorialnego państwa (Dz. U. z 1998 r. Nr 96, poz. 603).

\section{RAMY PRAWNO-INSTYTUCJONALNE I UDZIAL PARTII POLITYCZNYCH W WYBORACH DO SEJMU USTAWODAWCZEGO W 1919 ROKU NA PODKARPACIU}

W artykule zaprezentowano przygotowania i przebieg wyborów sejmowych na Podkarpaciu do pierwszego sejmu w dziejach odrodzonej II Rzeczypospolitej, a mianowicie do Sejmu 
Ustawodawczego, który miał uchwalić nową konstytucję. Zdefiniowane zostały w nim również pojęcia partii politycznej w okresie tworzenia się niepodległego państwa polskiego oraz zaprezentowano powstawanie instytucji oraz prawa, które były odpowiedzialne za przeprowadzenie wyborów. Podkarpacie jako region w okresie II Rzeczypospolitej nie było wydzielone administracyjnie tak jak współcześnie, ale geograficznie i historycznie było znane. Geograficznie pokrywało się z terenami tzw. Małopolski Środkowej, która była częścią większej całości jaką była Galicja, kojarzona głównie z częścią zachodnią i wschodnią. W artykule zostały również omówione pierwsze akty normatywne dotyczące pierwszych wyborów w niepodległym państwie polskim po 1918 r. Chodzi tutaj w szczególności o Ordynację wyborczą i kilka innych mniejszych aktów prawnych. Zaprezentowano także liczbę uprawnionych i wyborców, głosów ważnych

i nieważnych oraz frekwencję w okręgach wyborczych Podkarpacia w wyborach z dnia 26 stycznia 1919 r. do Sejmu Ustawodawczego oraz rozkład poparcia politycznego w poszczególnych okręgach wyborczych Podkarpacia. Obszar Podkarpacia zawierał się w następujących okręgach wyborczych: Nowy Sącz nr 40, Jasło nr 41, Tarnów nr 42, Rzeszów nr 43, Tarnobrzeg nr 44, Jarosław nr 45, Przemyśl nr 46. Okręgi te wyznaczono politycznie w ramach toczących się walk o granice, nie pokrywały się one także z niektórymi powiatami, ale z punktu widzenia geograficznego pokrywały się z obszarem Podkarpacia.

Słowa kluczowe: Podkarpacie, wybory 1919 r., Sejm Ustawodawczy, partie polityczne, II Rzeczpospolita.

DOI:10.7862/rz.2016.hss.75 